\title{
HUBUNGAN ANTARA EFIKASI DIRI DENGAN INTENSI BERWIRAUSAHA PADA SISWA KELAS XII SMK NEGERI 6 PALEMBANG
}

\author{
Yuliansyah $^{1}$, Novia Pahleni Jahin ${ }^{2}$ \\ Dosen Abdi Nusa Palembang, Mahasiswa Abdi Nusa Palembang \\ Sur-el : yuliansyah_abnus@yahoo.co.id
}

\begin{abstract}
The purpose of this study was to determine whether there is a relationship between self-efficacy and intention entrepreneurship in class XII Vocational School District 6 Palembang. The study hypothesis is that there is a positive correlation between self-efficacy and intention entrepreneurship to high school students Kejururan Negeri 6 Palembang. The population in this study were students Vocational School District 6 Palembang totaling 357 students, with the number of samples taken are 100 students who are determined using proportional random sampling technique. Data collection instruments used in this study is the scale of self-efficacy and intention scale entrepreneurship. Methods of data analysis using the Pearson product moment correlation. Based on this analysis, showed there was a significant positive relationship between self-efficacy and intention entrepreneurship to high school students SMK Negeri 6 Palembang with $r$ count $>r$ table $=0.370>$ 0.197 by 0.05. That is, the higher self-efficacy, the higher the intention entrepreneurship.
\end{abstract}

Keywords: Self-efficacy, Intention entrepreneurship, Entrepreneur

\begin{abstract}
Abstrak: Tujuan penelitian ini adalah untuk mengetahui ada tidaknya hubungan antara efikasi diri dengan intensi berwirausaha pada siswa kelas XII Sekolah Menengah Kejuruan Negeri 6 Palembang. Hipotesis penelitian adalah ada hubungan positif antara efikasi diri dengan intensi berwirausaha pada siswa Sekolah Menengah Kejururan Negeri 6 Palembang. Populasi dalam penelitian ini adalah siswa Sekolah Menengah Kejuruan Negeri 6 Palembang yang berjumlah 357 siswa, dengan jumlah sampel yang diambil yaitu 100 siswa yang ditentukan dengan menggunakan teknik proportional random sampling. Instrumen pengumpulan data yang digunakan dalam penelitian ini adalah skala efikasi diri dan skala intensi berwirausaha. Metode analisis data menggunakan korelasi product moment Pearson. Berdasarkan analisis tersebut, menunjukkan ada hubungan positif yang signifikan antara efikasi diri dengan intensi berwirausaha pada siswa Sekolah Menengah Kejuruan Negeri 6 Palembang dengan $r$ hitung $>r$ tabel $=0,370>0,197$ berdasarkan signifikansi 0,05. Artinya, semakin tinggi efikasi diri, semakin tinggi pula intensi berwirausahanya.
\end{abstract}

Kata Kunci: Efikasi Diri, Intensi Berwirausaha, Berwirausaha

\section{PENDAHULUAN}

Pendidikan di Indonesia dibagi menjadi tiga jenjang, yaitu (1) pendidikan dasar, (2) pendidikan menengah, dan (3) pendidikan tinggi. Menurut Undang Undang Nomor 20 Tahun 2003 Pasal 18 ayat (2), pendidikan menengah terdiri atas pendidikan menengah umum dan pendidikan menengah kejuruan. Pendidikan menengah kejuruan diselenggarakan oleh Sekolah Menengah Kejuruan (SMK) atau Madrasah Aliyah Kejuruan (MAK).

Pendidikan menengah kejuruan dikelompokkan dalam bidang kejuruan didasarkan pada perkembangan ilmu pengetahuan, teknologi dan atau seni, dunia industri atau dunia usaha, ketenagakerjaan baik secara nasional, regional maupun global, kecuali untuk program yang terkait dengan upaya-upaya pelestarian warisan budaya. Sejak tahun 1994 pemerintah melalui Departemen Pendidikan Nasional sudah melakukan standarisasi kurikulum pada seluruh Sekolah Menengah Kejuruan (SMK), yaitu kewajiban mengajarkan mata pelajaran kewirausahaan pada siswanya. Menurut Instruksi Presiden RI No. 4 Tahun 1995, 
kewirausahaan adalah semangat, sikap, perilaku dan kemampuan seseorang dalam menangani usaha dan atau kegiatan yang mengarah pada upaya mencari,menciptakan, menerapkan cara kerja, teknologi dan produk baru dengan meningkatkan efisiensi dalam rangka memberikan pelayanan yang lebih baik dan atau memperoleh keuntungan yang lebih besar.

Pada mata pelajaran kewirausahaan siswa diajarkan bagaimana cara untuk membuka usaha baru, bagaimana menjadi wirausahawan yang baik, bagaimana mengelola usahanya, apa saja faktor penyebab kegagalan dan cara menghadapi kegagalan apabila terjadi pada usahanya sehingga siswa bisa menjadi seseorang yang sukses melalui berwirausaha. Sekolah Menengah Kejuruan (SMK) sebagai bentuk satuan penyelenggara dari pendidikan menengah kejuruan yang berada di bawah Direktorat Pembinaan Sekolah Kejuruan, merupakan lembaga pendidikan yang berorientasi pada pembentukan kecakapan hidup, yaitu melatih peserta didik untuk menguasai keterampilan yang dibutuhkan oleh dunia kerja (termasuk dalambisnis dan industri), memberikan pendidikan tentang kewirausahaan, serta membentuk kecakapan hidup (life skill).

Siswa Sekolah Menengah Kejuruan (SMK) lebih ditekankan untuk melakukan praktik sehingga mereka berpengalaman dan mantap untuk langsung memasuki dunia kerja, tetapi ini tidak menutup kemungkinan para lulusan Sekolah Menengah Kejuruan (SMK) untuk dapat melanjutkan ke jenjang pendidikan yang lebih tinggi. Kurikulum kewirausahaan dan pembekalan keterampilan yang didapatkan tersebut, seharusnya dapat membuat siswa lebih mudah untuk bersaing di dunia kerja dengan berwirausaha. Namun, pada kenyataannya masih banyak siswa lulusan Sekolah Menengah Kejuruan (SMK) yang lebih memilih untuk bekerja dengan orang lain atau bahkan belum bekerja yang sering disebut dengan pengangguran.

Pengangguran merupakan salah satu masalah terbesar bagi Indonesia yang belum dapat terpecahkan hingga sekarang. Akan tetapi, jumlah pengangguran pada tahun 2014 diprediksikan menurun menjadi 7,24 juta orang (6,03\%). Jumlah ini lebih rendah dibandingkan dengan jumlah pengangguran terbuka saat ini yang berjumlah 7,29 juta orang $(6,25 \%)$, namun dari jumlah tersebut lulusan Sekolah Menengah Kejuruan (SMK) mempunyai kenaikan pengangguran tertinggi dibandingkan lulusan lain. Kepala BPS Suyamin menyebutkan sekitar $11,19 \%$ pengangguran atau sekitar 814 ribu orang, merupakan tamatan Sekolah Menengah Kejuruan (SMK). Angka tersebut meningkat dibanding Agustus 2012 yang sebesar 9,87\%. Artinya, tamatan Sekolah Menengah Kejuruan (SMK) lebih banyak pengangguran dibanding tamatan lainnya.

Menurut data terakhir Badan Pusat Statistik (BPS) Sumatera Selatan, Tingkat Pengangguran Terbuka (TPT) di Sumatera Selatan tahun 2012 mengalami penurunan sebesar 0,07\% dibandingkan tahun 2011 menjadi sebesar 5,70\%. Secara absolut jumlah pengangguran di Sumatera Selatan tahun 2012 masih relatif tinggi yaitu sebesar 213.441 orang, dimana $67,21 \%$ diantaranya belum bekerja. Sedangkan untuk tingkat pengangguran terdidik tahun 2012 di Sumatera Selatan naik cukup 
signifikan, dari sebesar $14,87 \%$ di tahun 2011 menjadi $18,32 \%$ atau terjadi kenaikan 3,45\%. Pengangguran sebesar $5,70 \%$ tersebut, 2,28\% diantaranya merupakan pengangguran tidak lulus Sekolah Dasar (SD), 3,67\% lulusan Sekolah Dasar (SD) sederajat, 5,70\% lulusan Sekolah Menengah Pertama (SMP) sederajat, 10,31\% lulusan Sekolah Menengah Atas (SMA) sederajat, dan $8,01 \%$ lulusan Perguruan Tinggi (PT). Pengangguran lulusan Sekolah Menengah Atas (SMA) sederajat memiliki kenaikan yang cukup drastis dari tahun 2011, yang berjumlah 3,27\% pada tahun 2011 menjadi 10,31\% pada tahun 2012. Tidak menutup kemungkinan bahwa diantara jumlah penganguran tersebut merupakan lulusan SMK Negeri 6 Palembang.

Wirausahawan merupakan salah satu cara untuk mengurangi jumlah pengangguran, sebelum individu melakukan kegiatan berwirausaha, individu tersebut terlebih dahulu harus memiliki niat yang disertai dengan tingkah laku yang disebut intensi. Intensi menurut Ajzen (2005) merupakan komponen dalam diri individu yang mengacu pada keinginan untuk melakukan tingkah laku tertentu. Bandura (dalam Wijaya, 2007: 119) menyatakan bahwa intensi merupakan suatu kebulatan tekad untuk melakukan aktivitas tertentu atau menghasilkan keadaan tertentu di masa depan.

Berdasarkan penjelasan di atas dapat disimpulkan bahwa intensi merupakan dasar dalam melakukan suatu tingkah laku termasuk dalam berwirausaha. Individu yang memiliki intensi sebelum ia berwirausaha, akan lebih mampu menghadapi segala resiko yang akan dihadapi dibandingkan dengan individu yang tidak memiliki intensi sebelum ia berwirausaha. Namun pada kenyataannya walaupun memiliki intensi atau niat untuk berwirausaha, masih sangat sulit bagi siswa lulusan Sekolah Menengah Kejuruan (SMK) untuk membuka usaha sendiri karena mereka tidak cukup memiliki efikasi diri dalam dirinya. Nasution (2011: 2) mengatakan efikasi diri yang tinggi sangat dibutuhkan untuk melakukan suatu tindakan khususnya untuk berwirausaha. Hal ini sesuai dengan pernyataan Bandura (1986) dan Lent at all (1994) (dalam Kurniawan, 2011 : 8) yang mengungkapkan adanya hubungan antara self efficacy dan intensi berwirausaha dengan demikian persepsi diri dan kemampuan diri berperan dalam membangun intensi. Sehingga jika seseorang memiliki self efficacy yang tinggi maka orang tersebut memiliki tingkat intensi dalam melakukan sesuatu lebih tinggi dibandingkan lainnya, dalam hal ini intensi berwirausaha.

Chaplin (2004) mendefinisikan intensi intention) sebagai (1) satu perjuangan guna mencapai satu tujuan; (2) ciri-ciri yang dapat dibedakan dari proses-proses psikologis yang mencakup referensi atau kaitannya dengan satu objek. Riyanti (2003) mengatakan bahwa intensi merupakan posisi seseorang dimensi problabilitas subjektif yang melibatkan suatu hubungan antara dirinya dengan beberapa tindakan. Intensi merupakan faktor motivasional yang mempengaruhi tingkah laku.

Kata "wirausaha" dalam Bahasa Indonesia adalah padanan dari kata berbahasa Perancis “entrepreneur". Kata “entrepreneur" diturunkan 
dari kata kerja "entreprende". Kata "wirausaha" merupakan gabungan dari kata "wira" yang berarti usaha, gagah, luhur, berani, teladan dan pejuang. Kata "usaha" yang berarti penciptaan kegiatan dan atau berbagai aktivitas bisnis (Masykur, 2007 ) Kewirausahaan merupakan kemampuan individu untuk menggunakan kesempatan melalui berbagai jalan (Rianto, dalam Sumarsono, 2013). Menurut Sunarya, dkk (2011) wirausaha adalah seseorang yang memutuskan untuk memulai suatu bisnis, sebagai pewaralaba (franchisor) menjadi terwaralaba (franchisee), memperluas sebuah perusahaan, membeli perusahaan yang sudah ada atau meminjam uang untuk memproduksi suatu jasa baru, serta merupakan menejer dan penyandang resiko. Sedangkan menurut Drucker (dalam Sunarya, dkk, 2011 : 11) wirausaha adalah seseorang yang memiliki kemampuan untuk menciptakan sesuatu yang baru dan berbeda.

Intensi kewirausahaan menurut Katz dan Gartner (Indarti dan Rostiani, 2008 ) dapat diartikan sebagai proses pencarian informasi yang dapat digunakan untuk mencapai tujuan pembentukan suatu usaha. Sebelum seseorang melakukan kegiatan berwirausaha harus memiliki niat atau keinginan. Menurut Indarti dan Kristiansen (Sumarsono 2013) intensi wirausaha seseorang terbentuk melalui tiga tahap yaitu motivasi (motivation), kepercayaan diri (belief) serta keterampilan dan kompetensi (skill dan competence). Berdasarkan definisi tersebut, peneliti menyimpulkan bahwa intensi berwirausaha adalah seberapa besar keinginan atau niat seseorang untuk mewujudkan keinginannya membuka usaha sendiri sekaligus membuka lapangan pekerjaan baru bagi orang lain maupun dirinya sendiri dengan mengelola usahanya sendiri ditambah dengan kreativitas yang dimilik

Wiggins, dkk (Supatra, 2009) mengemukakan beberapa faktor yang mempengaruhi intensi, yaitu :a. Past Behavior (tingkah laku yang lalu). Seseorang yang telah mempunyai intensi akan lebih kuat apabila sebelumnya sudah pernah melakukan suatu perilaku daripada yang baru melakukan suatu perilaku. b. Identitas Diri. Seseorang cenderung memiliki intensi untuk melakukan sesuatu secara konsisten apabila sesuai dengan identitas diri individu yang bersangkutan. Sebaliknya apabila tidak sesuai dengan identitas diri maka orang cenderung memiliki intensi yang rendah untuk melakukan suatu hal. c. Self Efficacy. Beberapa ahli meyakini bahwa intensi merupakan prediksi yang baik bagi tingkah laku pada orang yang memiliki self efficacy. Keyakinan berdasar pendapat bahwa orang yang mampu mengontrol tingkah laku dapat menghasilkan konsekuensi sukses dan tingkah lakunya, yaitu self efficacy yang tinggi. Seseorang yang memiliki self efficacy yang tinggi akan mempunyai kemampuan bertahan lebih lama dalam menyelesaikan suatu masalah sulit dibandingkan dengan orang yang memiliki self efficacy rendah.

Fasio dan Ewolden ( Supatra, 2009 ) mengatakan bahwa aspek-aspek intensi meliputi :

a. Situasi

Seseorang tidak dengan mudah mewujudkan intensi menjadi tingkah laku tertentu. Hal ini disebabkan oleh situasi tetap, 
yaitu ketidakleluasaan situasional sebagai akibat adanya norma-norma.

b. Waktu

Ketika individu berada di bawah tekanan waktu dan mengharuskan bertindak cepat, maka individu tersebut cenderung untuk memiliki intensim untuk melakukan suatu tindakan.

c. Kekhususan perilaku

Pemfokusan pada objek yang akan diaktualisasikan menjadi perilaku sesungguhnya. d. Individu

Intensi untuk melakukan perilaku tertentu antara individu satu dengan individu lain. Berdasarkan uraian di atas, dapat disimpulkan bahwa aspek-aspek intensi, yaitu : attitude toward the behavior, subjective norm, perceived behavioral control, situasi, waktu, kekhususan perilaku, dan individu.

Bandura (Indarti dan Rostiani, 2012) mendefinisikan efikasi diri sebagai kepercayaan seseorang atas kemampuan dirinya untuk menyelesaikan suatu pekerjaan. Atau dengan kata lain, kondisi motivasi seseorang yang lebih didasarkan pada apa yang mereka percaya daripada apa yang secara objektif benar. Efikasi diri merupakan perasaan, penilaian seseorang mengenai kemampuan dan kompetensi yang dimiliki untuk menyelesaikan tugas yang diberikan padanya. Efikasi diri bersifat subjektif karena menekankan pada keyakinan individu yang merupakan persepsinya terhadap kemampuannya. Manusia memiliki kemampuan yang memungkinkan dirinya untuk mengontrol pikiran, perasaan, serta perbuatannya dan bahwa pikiran, keyakinan serta perasaan seseorang mempengaruhi perilakunya (Astria, dalam Nasution, 2012 ).
Menurut Baron dan Byrne (2004) menyatakan self efficacy merupakan penilaian individu terhadap kemampuan atau kompetensinya dalammelakukan suatu tugas, mencapai suatu tujuan, dan menghasilkan sesuatu. Kemudian Bandura (Suseno, 2012 ) menyatakan bahwa keyakinan akan seluruh kemampuan ini meliputi kepercayaan diri, kemampuan menyesuaikan diri, kapasitas kognitif, kecerdasan dan kapasitas bertindak pada situasi yang penuh dengan tekanan. Selanjutnya, Bandura ( Suseno, 2012 5) mengatakan, jika seseorang percaya bahwa tidak memiliki kekuatan untuk memperoleh suatu hasil, maka orang tersebut tidak akan berusaha untuk membuat sesuatu terjadi. Sebaliknya, orang yang memiliki efikasi diri tinggi diyakini sebagai orang yang mampu berperilaku tertentu untuk dapat mencapai hasil yang diinginkan, selain itu mereka juga lebih giat dan lebih tekun dalam berusaha. Self efficacy merupakan kepercayaan individu atas kemampuannya dalam menyelesaikan pekerjaan, memegang peranan penting dalam mempengaruhi intensi seseorang (Sumarsono, 2013). Bandura (Nasution 2011) mengatakan bahwa efikasi diri pada dasarnya adalah hasil dari proses kognitif berupa keputusan, keyakinan atau keyakinan tentang sejauh mana individu memperkirakan kemampuan dirinya dalam melaksanakan tugas atau tindakan tertentu yang diperlukan untuk mencapai hasil yang diinginkan. Efikasi diri menekankan pada komponen keyakinan diri yang dimiliki seseorang dalam menghadapi situasi yang akan datang yang mengandung kekaburan, tidak dapat diramalkan, dan sering 
penuh dengan tekanan.

Meskipun efikasi diri memiliki suatu pengaruh sebab-musabab yang besar pada tindakan kita, bukan satu-satunya penentu tindakan. Efikasi diri berkombinasi dengan lingkungan, perilaku sebelumnya dan variabel-variabel personal lain, terutama harapan hasil untuk menghasilkan perilaku. Berdasarkan beberapa definisi di atas dapat disimpulkan bahwa efikasi diri adalah keyakinan diri seseorang terhadap kemampuan yang dimiliki dalam mengorganisir, menyelesaikan suatu tugas, mencapai suatu tujuan, dan menghasilkan sesuatu.

Bandura (Suseno, 2012) mengemukakan bahwa perbedaan tingkat efikasi diri dipengaruhi beberapa faktor, yaitu :

a. Sifat tugas yang dihadapi

Semakin kompleks dan sulit suatu tugas bagi seseorang maka semakin besar keraguan terhadap kemampuannya, sebaliknya jika individu dihadapkan pada tugas yang sederhana dan mudah maka dirinya sangat yakin pada kemampuannya untuk berhasil.

b. Intensif eksternal

Adanya intensif berupa hadiah (reward) dari orang lain untuk merefleksikan keberhasilan individu dalam menguasai atau melaksanakan suatu tugas akan meningkatkan efikasi dirinya. Reward yang tepat atau menarik akan meningkatkan motivasi seseorang. c. Status seseorang dalam lingkungan Seseorang yang memiliki status sosial lebih tinggi akan memiliki tingkat efikasi diri yang tinggi pula dibandingkan seseorang yang berstatus sosial lebih rendah. Status sosial tinggi membuat seseorang memperoleh penghargaan lebih dari orang lain sehingga memberikan pengaruh pula terhadap efikasi dirinya.

d. Informasi tentang kemampuan diri

Efikasi diri akan meningkat jika seseorang mendapatkan informasi yang positif tentang dirinya, demikian sebaliknya, efikasi diri akan menurun jika seseorang mendapatkan informasi negatif mengenai kemampuannya. Abdullah (Nasution, 2011 ) menyimpulkan berdasar pendapat para ahli bahwa faktor-faktor yang mempengaruhi efikasi diri meliputi komponen kecakapan atau kemampuan menyelesaikan suatu tugas dan keadaan situasional dimana situasi-situasi tertentu memerlukan kinerja yang lebih rumit dan membawa resiko yang lebih menakutkan daripada yang lain.

Berdasarkan uraian di atas dapat disimpulkan bahwa faktor yang mempengaruhi efikasi diri, yaitu : sifat tugas yang dihadapai, intensif eksternal, status seseorang dalam lingkungan dan informasi tentang kemampuan diri, komponen kecakapan atau kemampuan menyelesaikan suatu tugas dan keaadaan situasional yang memerlukan kinerja yang lebih rumit dan membawa resiko yang lebih sulit.

Berdasarkan pada teori belajar sosial yang dikemukakan oleh Bandura (Supatra, 2009) terdapat tiga aspek efikasi diri, yaitu :

\section{a. Efficacy Expectancy}

Harapan yang dapat membentuk perilaku yang tepat. Suatu keyakinan bahwa seseorang akan berhasil dalam bertindak sesuai dengan hasil yang diharapkan. Aspek ini menunjukkan bahwa harapan seseorang berkaitan dengan kesanggupan melakukan sesuatu yang dikehendaki.

b. Outcome Expectancy 
Harapan terhadap kemungkinan hasil dari suatu perilaku yaitu suatu perkiraan bahwa tingkah laku atau tindakan tertentu akan menyebabkan akibat tertentu yang bersifat khusus. Outcome expectancy mengandung keyakinan sejauh mana perilaku tertentu akan menimbulkan konsekuensi tertentu.

\section{c. Outcome Value}

Nilai yang mempunyai arti dari konsekuensi-konsekuensi yang terjadi bila suatu perilaku dan seseorang harus mempunyai outcome value yang tinggi untuk mendukung efficacy expectancy dan outcome expectancy. Corsini (Supatra, 2009 ) berpendapat bahwa terdapat aspek aspek efikasi diri yang meliputi :

\section{a. Kognisi}

Kemampuan seseorang memikirkan cara-cara yang digunakan dan merancang tindakan yang akan diambil untuk mencapai tujuan yang diharapkan. Tiap-tiap orang mempersiapkan diri dengan pemikiran pemikiran ke depan sehingga pada saat terjadi situasi yang tidak menyenangkan, maka dapat dilakukan tindakan yang tepat.

\section{b. Motivasi}

Kemampuan seseorang memotivasi diri melalui pikirannya untuk melakukan suatu tindakan dan kepatusan dalam mencapai tujuan yang diharapkan. Setiap orang berusaha untuk memotivasi diri dengan menetapkan keyakinan pada tindakan yang akan dilakukan, merencanakan tindakan yang akan direalisasikan. Motivasi dalam efikasi diri digunakan untuk memprediksi kesuksesan dan kegagalan seseorang.

c. Afeksi

Kemampuan mengatasi emosi yang timbul pada diri sendiri untuk mencapai tujuan yang diharapkan. Afeksi pribadi secara alami dalam diri seseorang dan berperan dalam menentukan intensitas pengalaman emosional. Afeksi ditunjukan dengan mengontrol kecemasan dan perasaan depresif yang menghalangi pola-pola fikir yang benar untuk mencapai tujuan.

d. Seleksi

Kemampuan untuk menyeleksi tingkah laku dan lingkungan yang tepat sehingga dapat mencapai tujuan yang diharapkan. Seleksi tingkah laku mempengaruhi perkembangan personal. Asumsi yang timbul pada aspek ini adalah ketidakmampuan orang dalam melakukan seleksi tingkah laku membuat orang tidak percaya diri, bingung dan mudah menyerah ketika menghadapi situasi yang sulit.

Berdasarkan uraian di atas dapat disimpulkan bahwa aspek-aspek efikasi diri, terdiri dari efficacy expectancy, outcome expectancy, outcome value, kognisi, motivasi, afeksi dan seleksi.

\section{METODOLOGI PENELITIAN}

Peneliti bermaksud untuk menyelidiki hubungan antara efikasi diri dengan intensi berwirausaha pada siswa kelas XII SMK Negeri 6 Palembang, maka rancangan penelitian yang digunakan dalam penelitian ini merupakan jenis penelitian non eksperimen karena peneliti hanya ingin melihat keterkaitan antara kedua variabel yang akan diteliti. Penelitian ini menggunakan jenis penelitian kuantitatif korelasional. Penelitian kuantitatif ini menekankan analisis pada data-data numerikal (angka) yang diolah melalui metode statistika (Hadi, dalam Nasution 
maka sampel dapat diambil antara $10-15 \%$ atau

\subsection{Variabel Penelitian}

Variabel dalam penelitian ini terdiri dari 2 yaitu variabel tergantung $(\mathrm{Y})$ dan variabel bebas $(\mathrm{X})$. Variabel tergantung $(\mathrm{Y})$ adalah intensi berwirausaha. Intensi berwirausaha adalah seberapa besar keinginan atau niat seseorang untuk mewujudkan keinginannya membuka usaha sendiri sekaligus membuka lapangan pekerjaan baru bagi orang lain maupun dirinya sendiri dengan mengelola usahanya sendiri ditambah dengan kreativitas yang dimiliki. Variabel bebas (X) adalah efikasi diri, yaitu keyakinan diri seseorang terhadap kemampuan yang dimiliki dalam mengorganisir, menyelesaikan suatu tugas, mencapai suatu tujuan, dan menghasilkan sesuatu.

\subsection{Populasi dan Sampel Penelitian}

Jumlah populasi dalam penelitian ini yang merupakan keseluruhan dari siswa kelas XII SMK Negeri 6 Palembang yaitu 357 orang siswa, yang terbagi menjadi 12 kelas dengan 6 kompetensi keahlian, yaitu busana butik sebanyak 66 orang, jasa boga sebanyak 100 orang, akomodasi perhotelan sebanyak 83 orang, kecantikan kulit sebanyak 31 orang, kecantikan rambut sebanyak 46 orang, dan patiseri sebanyak 31 orang.

Arikunto (2010) mengatakan apabila populasi penelitian kurang dari 100 maka sampel yang diambil adalah semuanya, namun apabila populasi penelitian berjumlah lebih dari 100
$20-25 \%$ atau lebih. Berdasarkan pernyataan tersebut, maka peneliti mengambil sampel 25\% dari jumlah populasi, yaitu 89 dibulatkan menjadi 100 orang. Selanjutnya jumlah sampel yang akan diambil di setiap kompetensi keahlian ditentukan dengan menggunakan proportional random sampling.

\section{$2.3 \quad$ Uji Hipotesis}

Pengujian hipotesis menggunakan analisis korelasi product moment dari Pearson (Azwar, 2005)

\section{HASIL PENELITIAN}

Setelah dilakukan uji normalitas dan uji linearitas maka selanjutnya dilakukan uji hipotesis yang berguna untuk mengetahui apakah hipotesis yang diajukan dapat diterima atau tidak. Pengujian hipotesis ini menggunakan teknik analisis Product Moment Person. Hasil analisis yang telah dilakukan menggunakan Product Moment Pearson, menunjukkan koefisien (rxy) sebesar 0,370 dengan $\mathrm{N}=100$ dengan taraf signifikan 0,05 diperoleh rtabel sebesar 0,197, maka rhitung $>$ rtabel, sehingga hipotesis yang berbunyi ada hubungan antara efikasi diri dengan intensi berwirausaha pada siswa kelas XII SMK Negeri 6 Palembang dapat diterima.

Koefisien korelasi menunjukkan bahwa ada hubungan positif yang signifikan antara efikasi diri dengan intensi berwirausaha pada siswa kelas XII SMK Negeri 6 Palembang. Bobot keeratan hubungan antara kedua variabel sebesar 13,69 didapatkan dengan rumus 
koefisien determinasi yaitu KD $=\mathrm{r} 2 \times 100 \%$. Artinya kedua variabel saling memberikan sumbangan sebesar $13,69 \%$ pada pihak lainnya yang dapat dijelaskan dari hubungan keduanya dan sisanya $86,31 \%$ merupakan sumbangan dari faktor lain. Hal ini dikarenakan penelitian ini hanya berfokus pada hubungan intensi berwirausaha dengan efikasi diri, sedangkan masih banyak faktor lain.

Menurut Sunarya, dkk (2011) wirausaha adalah seseorang yang memutuskan untuk memulai suatu bisnis, sebagai pewaralaba (franchisor) menjadi terwaralaba (franchisee), memperluas sebuah perusahaan, membeli perusahaan yang sudah ada atau meminjam uang untuk memproduksi suatu produk baru atau menawarkan suatu jasa baru, serta merupakan menejer dan penyandang resiko. Drucker (dalam Kurniawan, 2011) menyatakan bahwa wirausaha merupakan penyumbang terbesar perekonomian di Amerika dan bukan perusahaan-perusahaan besar berteknologi tinggi, melainkan dunia wirausaha yang menciptakan ribuan lapangan kerja. Oleh sebab itu, perlu adanya peningkatan jumlah pelaku usaha yang dapat memperbanyak lapangan pekerjaan yang merupakan salah satu cara untuk mengatasi pengangguran.

Sebelum melakukan suatu tindakan perlu adanya niat atau intensi dalam diri individu tersebut, begitu juga dengan berwirausaha. Intensi berwirausaha adalah seberapa besar keinginan atau niat seseorang untuk mewujudkan keinginannya membuka usaha sendiri yang dapat membuka lapangan pekerjaan baru bagi orang lain maupun dirinya sendiri dengan mengelola usahanya sendiri ditambah dengan kreativitas yang dimiliki. Intensi menjadi salah satu prediktor sukses jika seseorang akan berwirausaha. Semakin tinggi intensi seseorang maka kemungkinan sukses dalam berwirausaha semakin tinggi juga. Sebaliknya semakin rendah intensi seseorang maka kemungkinan suksesnya akan semakin rendah. Intensi berwirausaha juga dipengaruhi oleh banyak faktor, salah satunya self efficacy (Wiggins, dkk dalam Supatra 2009). Berdasarkan penelitian dari Kurniawan (2011), efikasi diri mempengaruhi intensi berwirausaha siswa.

Selanjutnya, hasil penelitian dari Segal, dkk (2005 ) mengatakan self efficacy adalah salah satu faktor yang digunakan untuk memprediksi intensi berwirausaha. Self efficacy ini mempengaruhi kepercayaan diri pada diri individu, bahwa individu tersebut memiliki kemampuan untuk bisa melakukan suatu tugas tertentu. Jika individu sudah memiliki self efficacy yang kuat, maka hal ini akan mempengaruhi kepercayaan diri yang ia miliki untuk bisa berwirausaha. Semakin kuat keyakinan individu terhadap keyakinan dirinya, maka kepercayaan dirinya untuk berwirausaha juga semakin besar. Selain kepercayaan diri, dalam berwirausaha individu juga harus mempunyai komitmen yang kuat. Jika individu menghadapi masalah, individu tersebut harus bisa memotivasi dirinya dan berjuang untuk mengatasi masalah tersebut.

Selain itu, individu tersebut harus siap menghadapi segala resiko yang akan dihadapinya, sehingga individu tersebut berani mengambil resiko. Jika individu merasa yakin bahwa ia memiliki kemampuan-kemampuan tersebut, maka intensi yang ada dalam dirinya akan menjadi lebih tinggi dari mereka yang tidak 
memiliki kemampuan tersebut. Berdasarkan uraian di atas dapat terlihat bahwa efikasi diri adalah salah satu faktor yang digunakan untuk memprediksi intensi berwirausaha. Semakin tinggi efikasi diri individu maka akan semakin tinggi intensi berwirausahanya dan semakin besar peluang kesuksesannya, sebaliknya semakin rendah atau sedikit efikasi diri individu maka akan semakin sedikit intensi berwirausahanya dan akan semakin kecil peluang kesuksesannya.

\section{SIMPULAN}

Berdasarkan analisis data terdapat hubungan positif yang signifikan antara efikasi diridengan intensi berwirausaha pada siswa kelas XII SMK Negeri 6 Palembang. Koefisien determinansi yang didapatkan sebesar 13,69\%. Artinya kedua variabel memiliki keeratan hubungan sebesar 13,69\%, baik sumbangan efikasi diri terhadap intensi berwirausaha pada diri siswa, maupun intensi berwirausaha terhadap efikasi diri pada diri siswa.

\section{DAFTAR RUJUKAN}

Ajzen, I. 2005. Attitudes, Personality and Behavior. Second Edition. Open University Press. New York.

Arikunto,S. Prof. Dr. 2010. Prosedur Penelitian Suatu Pendekatan Praktik Edisi Revisi 2010. Rineka Cipta. Jakarta.

Azwar, S. 2005. Penyusunan Skala Psikologi. Pustaka Pelajar. Yogyakarta.

Kurniawan, T.D. 2011. Intensi Berwirausaha Siswa Sekolah Menengah Kejuruan (SMK) Negeri 22 Jakarta: Peran Self Efficacy, LoC, Risk Taking Behavior, EQ dan AQ. Skripsi. Fakultas Psikologi Universitas Islam Negeri Syarif Hidayatullah. Jakarta.

Nasution, R. 2011. Hubungan antara Interaksi Sosial dalam Kelompok Sebaya dengan Self Efficacy pada Siswa Kelas XI SMA LTI Indo Global Mandiri Palembang. Skripsi (tidak diterbitkan). Sekolah Tinggi Ilmu Psikologi Abdi Nusa. Palembang.

Segal, G., Borgia, D., Schoenfeld, J. 2005. The Motivation to Become An Entrepreneur. International Journal of Entrepreneurial Behaviour and Research, Vol.11, No.1 (42-57).

Sunarya, dkk. 2011. Kewirausahaan. Yogyakarta : Penerbit Andi.

Supatra, A.A. 2009. Intensi Berwirausaha pada Mahasiswa ditinjau dari Self Efficacy. Skripsi. Semarang : Fakultas Psikologi Universitas Katolik Soegijapranata.

Wijaya, T. 2007. Hubungan Adversity Intelligence dengan Intensi Berwirausaha. Jurnal Manajemen dan Kewirausahaan,.Vol. 9 No. 2 (117-127) 